\title{
Analysis of Rainfall Runoff for Agricultural Watershed Area
}

\author{
Asmita B. Lakhote ${ }^{1}$, Dr.B.V.Khode ${ }^{2}$, Er. N.Z.Baisware ${ }^{3}$ \\ ${ }^{1}$ (Department of Civil Engineering, G.H.Raisoni College of Engineering/ Nagpur University, India) \\ ${ }_{2}^{2}$ (Department of Civil Engineering, G.H.Raisoni College of Engineering/ Nagpur University, India) \\ ${ }^{3}$ (Irrigation Department, Hydrology Project Division, India)
}

\begin{abstract}
Watershed, catchment and drainage basin are synonymous terms, describing an area surrounded by a ridge line, which drains its runoff through a single outlet. When it is referred to as an area that contributes its runoff to a stream or a river, it is called the catchment of that stream or river. For effective and good water quality management, it is necessary to assess changes in input loads rather than concentrations. The present research primarily aims at evaluating various rainfall runoff characteristics on agricultural watershed area by considering eight rain gauge station of Vena catchment located in Hinganghat District. This paper deals with comparison of observed runoff with SCS Model, Modified SCS Model, and Mockus Model.
\end{abstract}

Keywords: Rainfall-Runoff, Hinganghat Watershed, Mockus method, Modified SCS Method, SCS Method,

\section{Introduction}

Water is very useful parameter of the environment because it is connected with the soil, drainage streams, river, reservoirs, catchment, basin, vegetation, and atmosphere. Water is the principal carrier of sediment \& chemical pollutants. Some of the important parameters of study of the effects of watershed management projects are soil erosion \& sediment level in streams. For good and fruitful water quality management, it is necessary to analyse changes in input loads rather than concentrations. Different models are used to find the runoff from a watershed. The present watershed area having a geographical area of 4109 square kilometer and the average annual rainfall is around $1314.56 \mathrm{~mm}$. The rainfall, land use, soil classification, infiltration rate data were used for the estimation of the runoff for the study area also the runoff is computed using SCS Model, Modified SCS Model \& MOCKUS Model and comparison is made between observed runoff and runoff by these three models. Three hydrologic runoff modeling system is used to induce continuous water balance in Vena catchment throughout all seasons for study period from year 2008 to 2012.

The first detailed probe of SCS method was done by Sherman $(1942,1949)$ by giving graphical representation between direct runoff with storm rainfall. Andrews (1954) introduced a graphical process for analyzing runoff from rainfall for combinations of the amount of vegetative cover, soil pattern and type, and conservation practices. Mockus (1949) performed the extensive experimental work on surface runoff for ungauged watersheds he used information for his research work on antecedent rainfall, storm duration, soil, average annual temperature, and land use pattern. Ritter and Gardner (1991) reported on application of the SCS model to watersheds in central Pennsylvania form his analysis he repossess surface coal mines. Svoboda (1991) applied the curve number concept to assess the soil-moisture content, and simultaneously, the rainfall bestow to direct runoff and ground water. Hawkins (1996) performed experimental analysis which gives that the SCS method could be explained and used in inclined area hydrology and could predict the contributing area he suggested the estimation of curve numbers from analysis and empirical data. Surendra Kumar Mishra and Vijay P. Singh (2011) introduced some modification of SCS-CN method and derived analytically which is based on the Mockus method analyzed, they proposed modification and a general form of the SCS-CN method using data from five watersheds, the existing SCS-CN method, the proposed modification, and the Mockus method are compared. For their analysis they found that the modified version is to be more accurate than the current version.

This paper describes a use of hydrologic-erosion model for targeted field and data collection program to analyse rainfall-runoff relationship. The main objective of research work is to investigate and identify the significance of parameters to analyse runoff in respect to rainfall, by considering eight rain gauge discharge station (Arvimothi, Hamdapur, Hinganghat, Kanholibara, Wadgaon, Wardha and Warudbaji) on Vena River catchment of Hinganghat River Gauging Station of Wardha District. 


\section{Study Area}

Hinganghat is a city in the Wardha district in the Indian state of Maharashtra shown in Fig..1. The study area, named Hinganghat watershed, is located at Wardha city. The watershed having a geographical area of 4109 square kilometer, Fig.ure (1) shows the study area and its location. Physiographically, the watershed is divided into plan and pediments. Elevation in the watershed ranges from 550 to $820 \mathrm{~m}$ above mean sea level. Hinganghat is location at latitude of $20^{\circ} 32^{\prime} 58^{\prime \prime} \mathrm{N}$ and longitude $78^{\circ} 48^{\prime} 00^{\prime \prime} \mathrm{E}$. The extent of Catchment Lat $21.032^{\circ} \mathrm{N}$, Lon. $78.299^{\circ} \mathrm{E}$ left to $20.650^{\circ} \mathrm{N}, 79.367^{\circ} \mathrm{E}$, right \& Lat. $21.208^{\circ} \mathrm{N}$, Lon $78.736^{0} \mathrm{E}$ top to $20.545^{\circ} \mathrm{N}$ $78.809^{\circ} \mathrm{E}$ bottoms. The average annual precipitation at Hinganghat area for the last five years is approximately $1314.56 \mathrm{~mm}$. About $90 \%$ of this rainfall is received from November to April, and the major land use/land cover categories in the watershed are: Forest area, agricultural area, and mixed area (Data obtained from Hydrology project division, Nagpur).

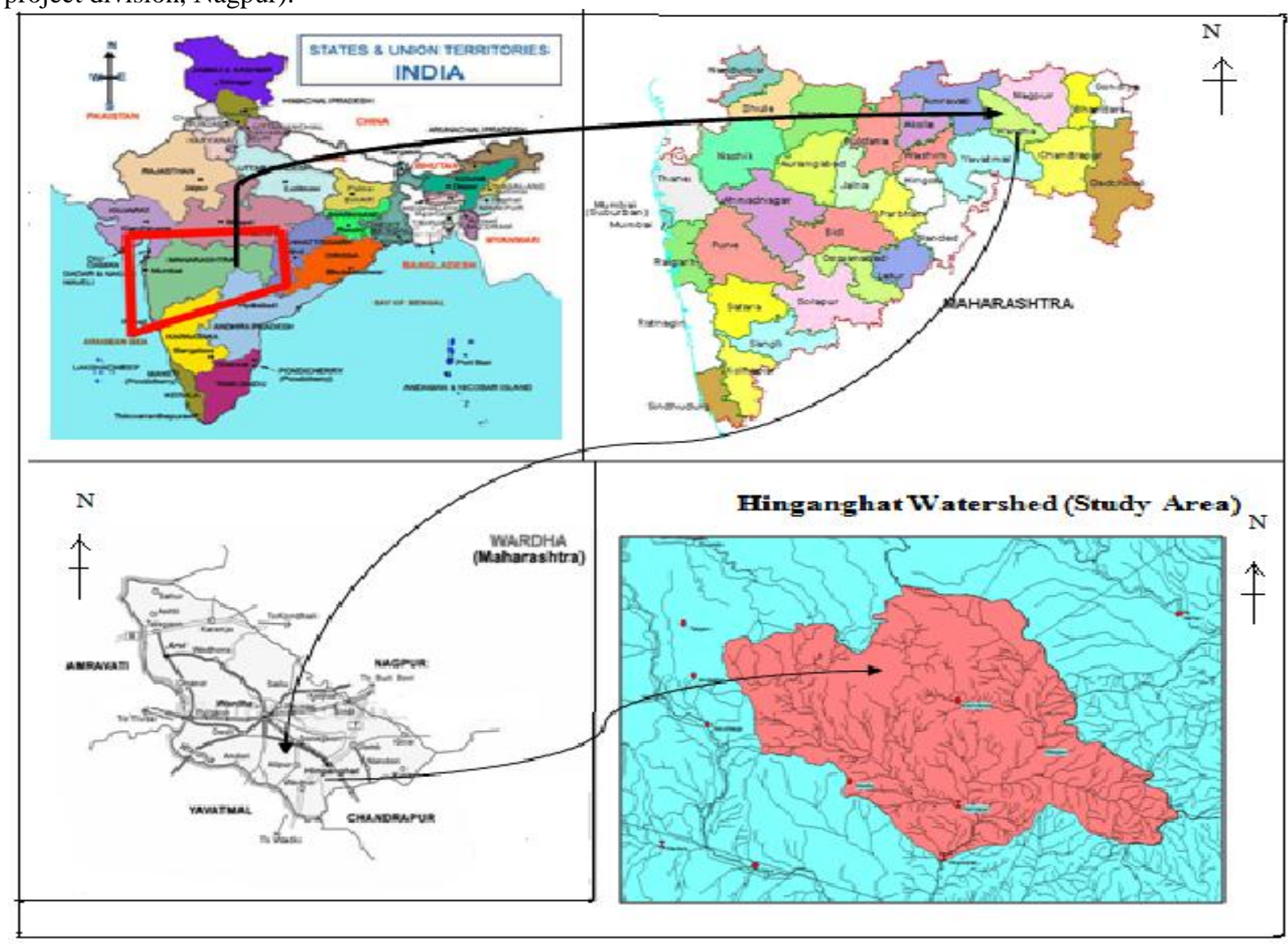

Fig.:1 Location of the Study Area (Hinganghat Watershed)

III. Mathematical Models Used For Rainfall-Runoff Analysis:

For calculation of runoff in Vena catchment it is more convenient to use SCS model and Mockus model. The Soil Conservation Service (SCS) model is most commonly used to estimate and analysed runoff from small- to medium-sized watershed area. The most critical limitation of the SCS model is that the ratio of the actual retention to the potential retention is same as ratio of actual runoff to potential runoff, but this limitation has not been experientially or theoretically proved by any one. The SCS Model is based on the two fundamental conjecture and water balance equation. The first conjecture equates the ratio of the amount of direct surface runoff $\mathrm{Q}$ to the total rainfall $\mathrm{P}$ with the ratio of the amount of infiltration and potential maximum retention $\mathrm{S}$. The second conjecture relates the initial abstraction Ia maximum retention.

\section{[1] The SCS-CN Model}

Following equation gives estimation of runoff using SCS method.

$\mathrm{Q}=\frac{(\mathrm{P}-\mathrm{Ia})^{2}}{\mathrm{P}-\mathrm{Ia}+\mathrm{S}}$

Where, $\mathrm{P}=$ the total rainfall, $\mathrm{Ia}=$ the initial abstraction, $\mathrm{Q}=$ the direct runoff and $\mathrm{S}=$ the potential maximum retention or infiltration. 


\section{[2] Modification in SCS-CN Method}

The SCS model was modified through theoretical composition and re-explicated to estimate subsurface drainage flow from rainfall. The composed theory is that when accumulated subsurface drainage flow is plotted versus accrued infiltration, subsurface drainage flow starts after some infiltration has accrued and the relationship becomes relating to a line of $45^{\circ}$ slope, just as the common SCS rainfall-runoff relationship. Modification of the SCS-CN method is introduced and produced to estimate the $\mathrm{CN}$ for subsurface drainage flow. In the method of defining $\mathrm{CN}$ for drainage flow, it was observed that the curve number varied with rainfall amount.

$$
\begin{array}{r}
\mathrm{Q}=\frac{(\mathrm{P}-\mathrm{Ia}) \times \mathrm{P}}{\mathrm{S}+\mathrm{a}(\mathrm{P}-\mathrm{Ia})} \\
a=\frac{1}{2}-\frac{s}{P}+\sqrt{\frac{1}{4}+\frac{S}{P}}
\end{array}
$$

Where, $a=1 / 2$ (for a modified method), Ia = the initial abstraction, $\mathrm{Q}=$ the direct runoff $\mathrm{S}=$ surface maximum retention, and $\mathrm{P}=$ rainfall in $\mathrm{mm}$.

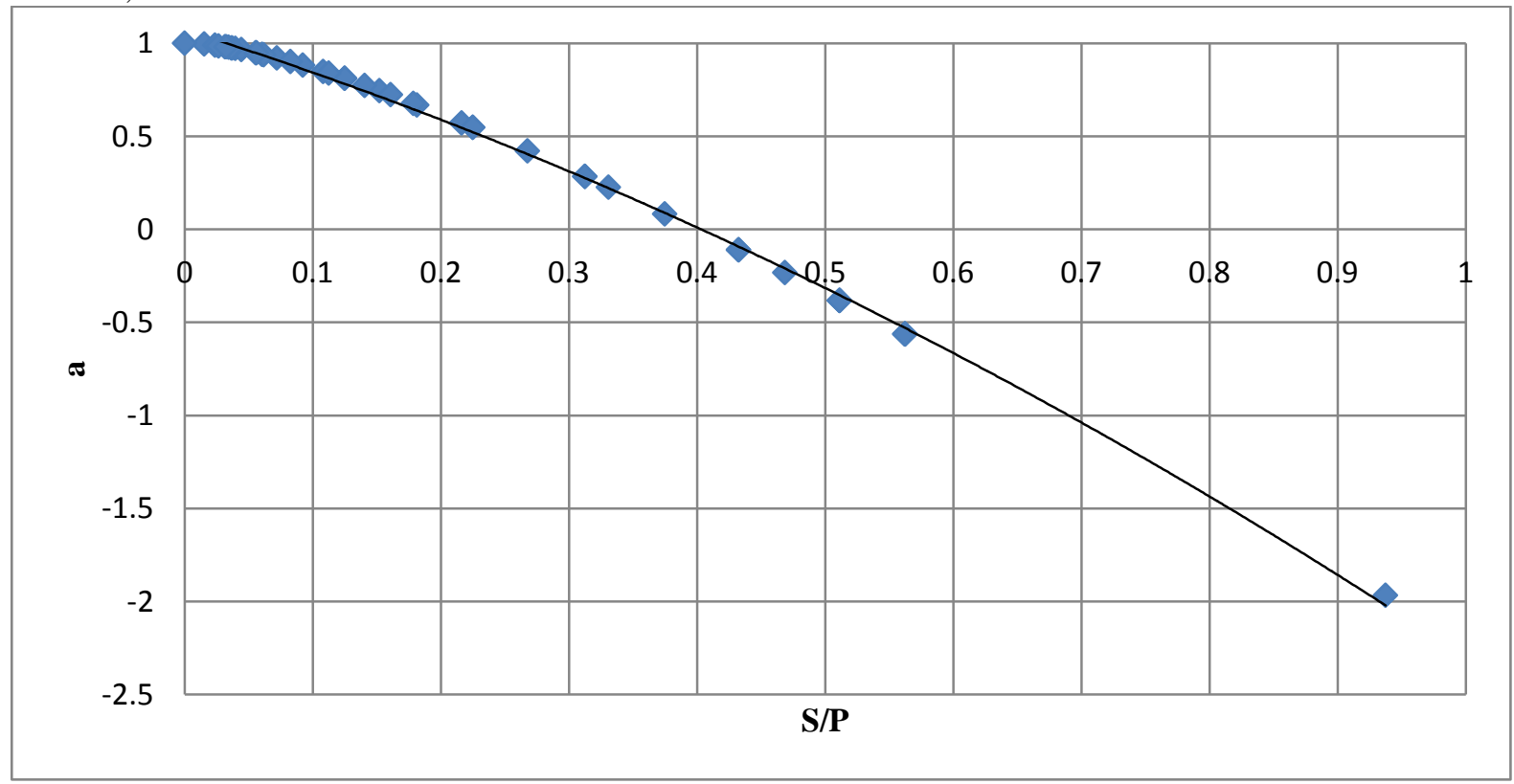

Fig.. 2 Variation of modified SCS parameter 'a' with S/P ratio (Surface maximum retention / rainfall in mm)

The SCS Model conjecture [1] is developed from the derived rainfall-runoff relation which is expressed by Mockus (1949) as follows:

$$
\mathrm{Q}=(\mathrm{P}-\mathrm{Ia})\left(1-10^{-\mathrm{bp}}\right)
$$

Where, $\quad \mathrm{b}=\frac{1}{\mathrm{~S}} \times \frac{1}{\text { Loge10 }}$

Where, $\mathrm{P}=$ the total rainfall $(\mathrm{mm}), \mathrm{Q}=$ the direct runoff $(\mathrm{mm})$, Ia and $\mathrm{b}=$ fitting coefficient (an index that depends on an antecedent moisture condition, vegetative cover, land use, time of year, storm duration, and soil type). The parameter $\mathrm{b}$ can be interpreted as a reasonable variation of $\mathrm{CN}$, with the difference that the latter is a non-dimensional quantity in a given system of units, and the former a dimensional quantity. The potential maximum retention $\mathrm{S}$ is commonly explained in terms of a runoff curve number $(\mathrm{CN})$ through the relationship given below:

$$
\mathrm{CN}=\frac{25400}{254+\mathrm{S}}
$$

Where S, 25400, and 254 are given in $\mathrm{mm}$. By knowing land used pattern $\mathrm{CN}$ is determined 
Table 1: The Present Land Used Pattern for Hinganghat Watershed Area

\begin{tabular}{|c|c|c|c|}
\hline Sr. No. & Land Use / Cover Category & Area ( Sq. Km) & Total Geological Area (in \%) \\
\hline 1 & Agricultural Land (AL) & 3491 & 84.959 \\
\hline 2 & Forest Land (FL) & 606 & 14.748 \\
\hline 3 & Mixed Land (ML) & 12 & 0.292 \\
\hline & & Total Area & $\mathbf{4 1 0 9}$ \\
\hline
\end{tabular}

\section{Comparison Of Observed Runoff With Existing Models:}

To compare observed runoff results with the SCS method Eq. (1), the modified method Eq. (2) and Mockus method Eq. (4). For given $\mathrm{K}=\mathrm{Q} / \mathrm{P}$ which explains the functional behavior of the SCS-CN method.

Table 2. Comparison of Observed Runoff with SCS, Modified SCS and Mockus Method For Station Arvimothi

\begin{tabular}{|c|c|c|c|c|c|c|c|c|c|c|}
\hline \multirow{2}{*}{ Year } & \multicolumn{4}{|c|}{ Observed } & \multicolumn{2}{c|}{ Mockus Method } & \multicolumn{2}{c|}{$\begin{array}{c}\text { Modified SCS } \\
\text { Method }\end{array}$} & \multicolumn{2}{c|}{ SCS Method } \\
\cline { 2 - 12 } & $\mathrm{P}(\mathrm{mm})$ & $\mathrm{Q}(\mathrm{mm})$ & $\mathrm{K}=\mathrm{Q} / \mathrm{P}$ & $\mathrm{S}$ & $\mathrm{Q}(\mathrm{mm})$ & Ratio $^{1}$ & $\mathrm{Q}(\mathrm{mm})$ & Ratio $^{2}$ & $\mathrm{Q}(\mathrm{mm})$ & Ratio $^{3}$ \\
\hline 2008 & 26.11 & 24.99 & 0.957 & 1.125 & 28.346 & 1.1344 & 23.96 & 0.9588 & 21.76 & 0.8707 \\
\hline 2009 & 16.30 & 15.18 & 0.931 & 2.5 & 14.229 & 0.9377 & 13.21 & 0.8706 & 12.19 & 0.8036 \\
\hline 2010 & 14.43 & 13.30 & 0.922 & 1.125 & 12.099 & 0.9096 & 11.31 & 0.8504 & 10.18 & 0.7653 \\
\hline 2011 & 25.81 & 24.69 & 0.956 & 1.125 & 23.711 & 0.9605 & 22.12 & 0.8960 & 20.80 & 0.8425 \\
\hline 2012 & 11.93 & 10.81 & 0.906 & 1.125 & 9.638 & 0.8917 & 8.81 & 0.8152 & 7.66 & 0.7087 \\
\hline
\end{tabular}

Table 3. Comparison of Observed Runoff with SCS, Modified SCS and Mockus Method For Station Hamdapur

\begin{tabular}{|c|c|c|c|c|c|c|c|c|c|c|}
\hline \multirow{2}{*}{ Year } & \multicolumn{4}{|c|}{ Observed } & \multicolumn{2}{c|}{ Mockus Method } & \multicolumn{2}{c|}{ Modified SCS Method } & \multicolumn{2}{c|}{ SCS Method } \\
\cline { 2 - 11 } & $\mathrm{P}(\mathrm{mm})$ & $\mathrm{Q}(\mathrm{mm})$ & $\mathrm{K}=\mathrm{Q} / \mathrm{P}$ & $\mathrm{S}$ & $\mathrm{Q}(\mathrm{mm})$ & Ratio $^{1}$ & $\mathrm{Q}(\mathrm{mm})$ & Ratio $^{2}$ & $\mathrm{Q}(\mathrm{mm})$ & Ratio $^{3}$ \\
\hline 2008 & 11.85 & 10.73 & 0.905 & 1.125 & 9.619 & 0.8969 & 9.01 & 0.8401 & 8.07 & 0.7524 \\
\hline 2009 & 10.50 & 9.38 & 0.893 & 1.125 & 8.158 & 0.8701 & 7.66 & 0.8171 & 6.68 & 0.7124 \\
\hline 2010 & 22.39 & 21.26 & 0.950 & 1.125 & 20.543 & 0.9662 & 18.90 & 0.8888 & 17.73 & 0.8339 \\
\hline 2011 & 19.64 & 18.51 & 0.943 & 1.125 & 17.771 & 0.9600 & 16.47 & 0.8895 & 14.76 & 0.7976 \\
\hline 2012 & 15.00 & 13.88 & 0.925 & 1.125 & 12.826 & 0.9244 & 11.71 & 0.8440 & 10.50 & 0.7571 \\
\hline
\end{tabular}

Table 4. Comparison of Observed Runoff with SCS, Modified SCS and Mockus Method For Station Hinganghat

\begin{tabular}{|c|c|c|c|c|c|c|c|c|c|c|}
\hline \multirow{2}{*}{ Year } & \multicolumn{4}{|c|}{ Observed } & \multicolumn{2}{c|}{ Mockus Method } & Modified SCS Method & \multicolumn{2}{c|}{ SCS Method } \\
\cline { 2 - 11 } & $\mathrm{P}(\mathrm{mm})$ & $\mathrm{Q}(\mathrm{mm})$ & $\mathrm{K}=\mathrm{Q} / \mathrm{P}$ & $\mathrm{S}$ & $\mathrm{Q}(\mathrm{mm})$ & Ratio $^{1}$ & $\mathrm{Q}(\mathrm{mm})$ & Ratio $^{2}$ & $\mathrm{Q}(\mathrm{mm})$ & Ratio $^{3}$ \\
\hline 2008 & 15.48 & 14.36 & 0.927 & 1.125 & 13.19 & 0.9190 & 12.48 & 0.8692 & 11.46 & 0.7984 \\
\hline 2009 & 21.14 & 20.02 & 0.947 & 1.125 & 19.04 & 0.9513 & 17.74 & 0.8864 & 16.58 & 0.8282 \\
\hline 2010 & 29.24 & 28.11 & 0.962 & 1.125 & 27.37 & 0.9735 & 25.29 & 0.8997 & 23.91 & 0.8506 \\
\hline 2011 & 17.12 & 16.00 & 0.934 & 1.125 & 15.12 & 0.9452 & 13.91 & 0.8693 & 12.81 & 0.8010 \\
\hline 2012 & 11.74 & 10.62 & 0.904 & 1.125 & 9.35 & 0.8802 & 8.75 & 0.8242 & 7.67 & 0.7227 \\
\hline
\end{tabular}

Table 5. Comparison of Observed Runoff with SCS, Modified SCS and Mockus Method For Station Kanholibara

\begin{tabular}{|c|c|c|c|c|c|c|c|c|c|c|}
\hline \multirow{2}{*}{ Year } & \multicolumn{4}{|c|}{ Observed } & \multicolumn{2}{c|}{ Mockus Method } & Modified SCS Method & \multicolumn{2}{c|}{ SCS Method } \\
\cline { 2 - 11 } & $\mathrm{P}(\mathrm{mm})$ & $\mathrm{Q}(\mathrm{mm})$ & $\mathrm{K}=\mathrm{Q} / \mathrm{P}$ & $\mathrm{S}$ & $\mathrm{Q}(\mathrm{mm})$ & Ratio $^{1}$ & $\mathrm{Q}(\mathrm{mm})$ & Ratio $^{2}$ & $\mathrm{Q}(\mathrm{mm})$ & Ratio $^{3}$ \\
\hline 2008 & 17.50 & 16.38 & 0.936 & 1.125 & 15.37 & 0.9384 & 14.32 & 0.8748 & 13.26 & 0.8095 \\
\hline 2009 & 19.50 & 18.38 & 0.942 & 1.125 & 17.52 & 0.9537 & 16.03 & 0.8723 & 14.79 & 0.8049 \\
\hline 2010 & 19.69 & 18.57 & 0.943 & 1.125 & 17.76 & 0.9566 & 16.26 & 0.8756 & 15.08 & 0.8124 \\
\hline 2011 & 23.24 & 22.11 & 0.952 & 1.125 & 21.27 & 0.9618 & 19.71 & 0.8913 & 18.50 & 0.8369 \\
\hline 2012 & 20.45 & 19.33 & 0.945 & 1.125 & 18.32 & 0.9476 & 17.17 & 0.8884 & 16.06 & 0.8308 \\
\hline
\end{tabular}


Table 6. Comparison of Observed Runoff with SCS, Modified SCS and Mockus Method For Station Wadgaon

\begin{tabular}{|c|c|c|c|c|c|c|c|c|c|c|c|}
\hline \multirow{2}{*}{ Year } & \multicolumn{4}{|c|}{ Observed } & \multicolumn{2}{c|}{ Mockus Method } & \multicolumn{2}{c|}{ Modified SCS Method } & \multicolumn{2}{c|}{ SCS Method } \\
\cline { 2 - 14 } & $\mathrm{P}(\mathrm{mm})$ & $\mathrm{Q}(\mathrm{mm})$ & $\mathrm{K}=\mathrm{Q} / \mathrm{P}$ & $\mathrm{S}$ & $\mathrm{Q}(\mathrm{mm})$ & Ratio $^{1}$ & $\mathrm{Q}(\mathrm{mm})$ & Ratio $^{2}$ & $\mathrm{Q}^{2}(\mathrm{~mm})$ & Ratio $^{3}$ \\
\hline 2008 & 29.82 & 28.69 & 0.962 & 1.125 & 27.99 & 0.9754 & 25.80 & 0.8990 & 24.40 & 0.8504 \\
\hline 2009 & 24.25 & 23.13 & 0.954 & 1.125 & 22.17 & 0.9588 & 20.51 & 0.8869 & 19.17 & 0.8290 \\
\hline 2010 & 24.96 & 23.84 & 0.955 & 1.125 & 22.90 & 0.9606 & 21.27 & 0.8920 & 19.95 & 0.8370 \\
\hline 2011 & 24.96 & 23.84 & 0.955 & 2.125 & 23.90 & 1.0025 & 22.27 & 0.9340 & 20.95 & 0.8789 \\
\hline 2012 & 16.17 & 15.04 & 0.930 & 1.125 & 13.80 & 0.9172 & 12.99 & 0.8638 & 11.86 & 0.7883 \\
\hline
\end{tabular}

Table 7. Comparison of Observed Runoff with SCS, Modified SCS and Mockus Method For Station Wardha

\begin{tabular}{|c|c|c|c|c|c|c|c|c|c|c|c|}
\hline \multirow{2}{*}{ Year } & \multicolumn{4}{|c|}{ Observed } & \multicolumn{2}{c|}{ Mockus Method } & \multicolumn{3}{c|}{$\begin{array}{c}\text { Modified SCS } \\
\text { Method }\end{array}$} & \multicolumn{2}{c|}{ SCS Method } \\
\cline { 2 - 14 } & $\mathrm{P}(\mathrm{mm})$ & $\mathrm{Q}(\mathrm{mm})$ & $\mathrm{K}=\mathrm{Q} / \mathrm{P}$ & $\mathrm{S}$ & $\mathrm{Q}(\mathrm{mm})$ & Ratio $^{1}$ & $\mathrm{Q}(\mathrm{mm})$ & Ratio $^{2}$ & $\mathrm{Q}(\mathrm{mm})$ & Ratio $^{3}$ \\
\hline 2008 & 16.52 & 15.40 & 0.932 & 1.125 & 14.43 & 0.9373 & 13.43 & 0.8725 & 12.38 & 0.8042 \\
\hline 2009 & 15.06 & 13.93 & 0.925 & 1.125 & 13.01 & 0.9339 & 11.90 & 0.8544 & 10.82 & 0.7769 \\
\hline 2010 & 29.60 & 28.48 & 0.962 & 1.125 & 27.79 & 0.9760 & 25.68 & 0.9019 & 24.36 & 0.8554 \\
\hline 2011 & 17.03 & 15.90 & 0.934 & 1.125 & 14.95 & 0.9402 & 13.81 & 0.8683 & 12.70 & 0.7986 \\
\hline 2012 & 13.12 & 12.00 & 0.914 & 1.125 & 10.63 & 0.8862 & 9.81 & 0.8176 & 8.51 & 0.7095 \\
\hline
\end{tabular}

Table 8. Comparison of Observed Runoff with SCS, Modified SCS and Mockus Method For Station Warudbaji

\begin{tabular}{|c|c|c|c|c|c|c|c|c|c|c|}
\hline Year & \multicolumn{4}{|c|}{ Observed } & \multicolumn{2}{|c|}{ Mockus Method } & \multicolumn{2}{|c|}{ Modified SCS Method } & \multicolumn{2}{|c|}{ SCS Method } \\
\hline 2008 & 18.59 & 17.47 & 0.939 & 1.125 & 16.73 & 0.9579 & 15.15 & 0.8672 & 13.95 & 0.7987 \\
\hline 2009 & 24.30 & 23.18 & 0.954 & 1.125 & 22.28 & 0.9615 & 20.66 & 0.8915 & 19.40 & 0.8369 \\
\hline 2010 & 19.67 & 18.55 & 0.943 & 1.125 & 17.39 & 0.9377 & 16.19 & 0.8729 & 14.92 & 0.8042 \\
\hline
\end{tabular}

Table 9. Performance Evaluation of models showing Standard error and Coefficient of Determination

\begin{tabular}{|c|c|c|c|c|c|c|}
\hline \multirow{2}{*}{ GD Station Name } & \multicolumn{3}{|c|}{ Standard error(mm) } & \multicolumn{3}{c|}{ Coefficient of Determination } \\
\cline { 2 - 7 } & Model 1 & Model 2 & Model 3 & Model 1 & Model 2 & Model 3 \\
\hline Arvimothi & 0.5406 & 5.5116 & 9.4511 & 0.9998 & 0.9820 & 0.9471 \\
\hline Hamdapur & 2.7893 & 5.7758 & 9.2383 & 0.9933 & 0.9712 & 0.9765 \\
\hline Hinganghat & 2.9059 & 6.3108 & 9.6185 & 0.9950 & 0.9264 \\
\hline Kanholibara & 2.6112 & 6.5051 & 9.8506 & 0.9964 & 0.9779 & 0.9493 \\
\hline Wadgaon & 2.6542 & 7.4146 & 11.2048 & 0.9974 & 0.9797 & 0.9537 \\
\hline Wardha & 2.8215 & 6.3893 & 9.7724 & 0.9949 & 0.9739 & 0.9390 \\
\hline Warudbaji & 0.7909 & 1.0656 & 1.7172 & 0.9962 & 0.9802 & 0.9540 \\
\hline
\end{tabular}

\section{V.Results And Discussions}

A comparative analysis of the observed runoff is made with SCS method, the modified version of SCS, and the Mockus method was performed using eight rain gauge stations of catchment area as shown in Table 2,3,4,5,6,7,8. From Table 2,3,4,5,6,7,8 it is observed that the runoff by SCS model is very less as compare to other models so by considering more number of catchment we can further increase the model efficiency \&from analysis it is found that SCS model is best for this catchment area.The resulting standard errors and coefficients of determination are shown in Table 9. As the standard error is dimensional it cannot be used for inter comparison of a model's performance to various applications. Fig. 3 shows variation rainfall with observed Runoff, estimated runoff by SCS Model, Modified SCS Model and Mockus Model. The relationship given in Fig. 4 shows that comparison of data between observed runoff and runoff by SCS Model, Modified SCS Model and Mockus model that the percentage difference is well within $\pm 10 \%$. By considering all eight rain gauge station it is observed that the average annual rainfall for the catchment is about $1314.56 \mathrm{~mm}$ and the average runoff at catchment $104.95 \mathrm{~mm}$. It is evident that the average annual runoff is much less as compared to average annual rainfall of the watershed 
under study. This clearly indicates that runoff is being trapped by various water impounding bodies in the watershed such as minor, medium and major dams, KT weirs etc. Lower Wuna, Bor and Dham are some among them.

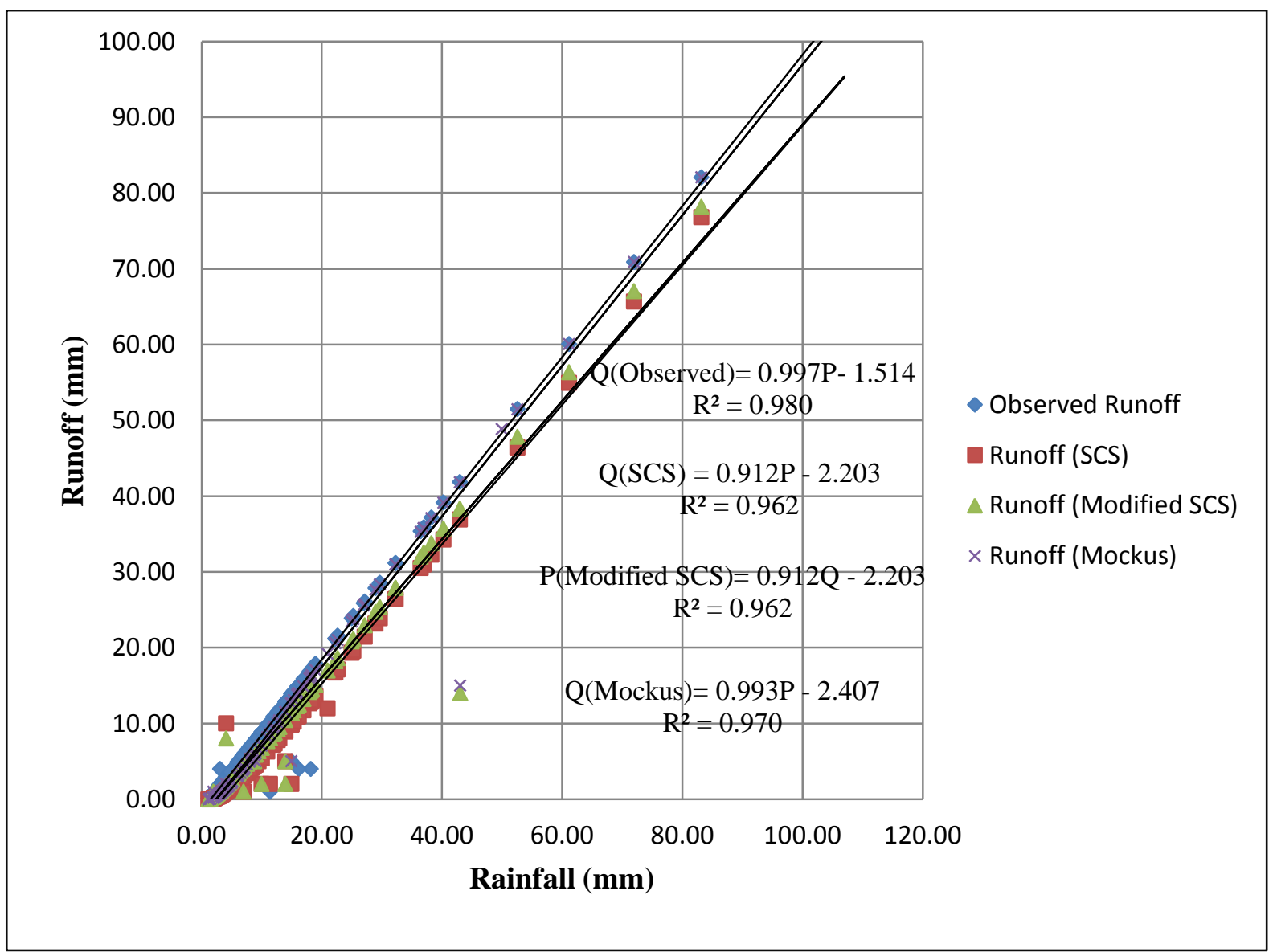

Fig. 3 Variation of Rainfall with observed runoff, runoff by SCS Model, Modified SCS Model and Mockus Model

\section{Equation Generated to Calculate Runoff in Vena Catchment}

After performing experimental analysis the relationship between Rainfall (mm) and Runoff (mm) by considering three models is graphically represented in Fig 3. The relationship obtained by regression analysis for the maximum value of Runoff by these models is shown in equation 5, 6, 7and 8:

A. Relationship between Observed Runoff and Rainfall

$\mathrm{Q}($ Observed $)=0.997 \mathrm{P}-1.514$ with $\quad \mathrm{R}^{2}=0.980$

B. Relationship between Runoff by SCS Model and Rainfall $\mathrm{Q}(\mathrm{SCS})=0.912 \mathrm{P}-2.203$ with $\mathrm{R}^{2}=0.962$

C. Relationship between Runoff by Modified SCS Model and Rainfall $\mathrm{Q}$ (Modified SCS) $=0.912 \mathrm{P}-2.203$ with $\mathrm{R}^{2}=0.962$

D. Relationship between Runoff by Mockus Model and Rainfall $\mathrm{Q}$ (Mockus) $=0.993 \mathrm{P}-2.407$ with $\mathrm{R}^{2}=0.970$ 


\section{Validation Of Data}

The validation of proposed analysis for runoff has been done by comparing the value of observed Runoff and Runoff by SCS Model, Modified SCS Model and Mockus model presented in this research paper. The observed runoff and estimated runoff by different models is presented in the paper Eight Rain Gauges stations have been taken up for validation. Fig. 3 shows Variation of Rainfall with observed runoff, runoff by SCS Model, Modified SCS Model and Mockus Model. It can be obtained from Fig.4 the percentage difference between observed runoff and runoff by Models is well within range of $\pm 10 \%$. Table (9) explains performance evaluation showing Standard error and Coefficient of Determination of three models.

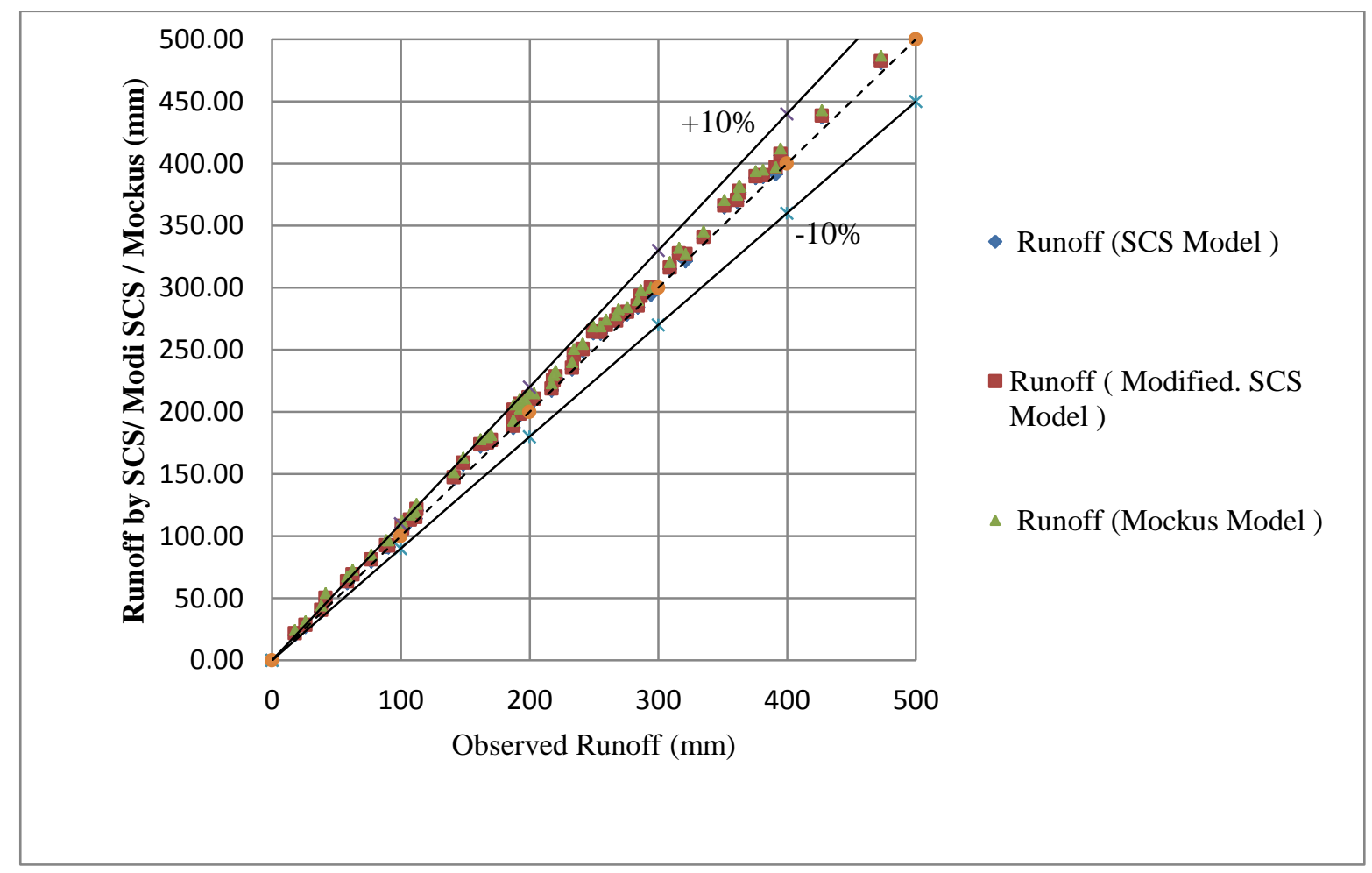

Fig. 4 Combined Graph shows Percentage Variation of observed Runoff with estimated runoff using SCS Model, Modified SCS Model and Mockus Model

\section{Conclusion}

The different methods were used to determine runoff for eight rain gauge station in Hinganghat watershed area. The study is conducting on important parameter affecting the discharge from the catchment area. The analysis of runoff is done by comparing observed runoff with SCS Model modified SCS model and Mockus Model, the percentage difference between observed runoff and runoff by Models is well within range of $\pm 10 \%$. The rainfall- runoff analysis clearly indicates that availability of runoff at Hinganghat River Gauging Station is low, which discourages any further construction of water bodies in the watershed.

\section{NOTATION}

$\mathrm{P}=$ the total rainfall $(\mathrm{mm})$,

Ia $=$ the initial abstraction,

$\mathrm{CN}=$ curve number

$\mathrm{b}=$ fitting coefficient (dimensionless)

$\mathrm{Q}=$ the direct runoff, $(\mathrm{mm})$

$\mathrm{S}=$ the potential maximum retention or infiltration $(\mathrm{mm})$ and

Ratio $^{1}=$ Runoff by Mockus Model $\left(Q_{\text {mockus }}\right) /$ Observed Runoff $\left(\mathrm{Q}_{\text {observed }}\right)$

Ratio $^{2}=$ Runoff by Modified SCS Model $\left(\mathrm{Q}_{\text {modi.SCS }}\right) /$ Observed Runoff $\left(\mathrm{Q}_{\text {observed }}\right)$

Ratio $^{3}=$ Runoff by SCS Model $\left(\mathrm{Q}_{\mathrm{SCS}}\right) /$ Observed Runoff $\left(\mathrm{Q}_{\text {observed }}\right)$

Model 1=SCS Model

Model 2=Modified SC S Model

Model 3=Mockus Model 


\section{References}

[1] Andrews, R. G. (1954). "The use of relative infiltration indices in computing runoff." Cited in Rainfall-runoff relationship, V. P. Singh, ed.,Water Resources Publications, Littleton, Colo.

[2] Hawkins, R. H. (1993). "Asymptotic determination of runoff curve numbers from data." J. Irrig. and Drain. Engrg., ASCE, 119(2), 334-345.

[3] Mockus, V. (1949). “Estimation of total (peak rates of) surface runoff for individual storms.' Exhibit A of Appendix B, Interim Survey Rep.Grand (Neosho) River Watershed, USDA, Washington, D.C.

[4] Ritter, J. B., and Gardner, T. W. (1991). "Runoff curve numbers for reclaimed surface mines in Pennsylvania.' J. Irrig. and Drain. Engrg.,ASCE, 117(5), 656-666.

[5] Sherman, L. K. (1942). "Hydrograph of runoff." Physics of the Earth,IX, hydrology, O. E. Meinzer, ed., McGraw-Hill, New York.

[6] Sherman, L. K. (1949). "The unit hydrograph method." Physics of theEarth, IX, hydrology, O. E. Meinzer, ed., McGraw-Hill, New York.

[7] Svoboda, A. (1991). "Changes in flood regime by use of the modified curve number method.' Hydrol. Sci. J., 36(5/10), 461-470

[8] Surendra Kumar Mishral and Vijay P. Singh, (2011) "Another Look at SCS-CN Method" Journal of Hydrologic Engineering, Vol. 4, No. 3, July, 1999. ASCE 